\title{
Lidar survey in the Brú na Bóinne World Heritage Site
}

\section{Stephen Davis, Conor Brady, William Megarry and Kevin Barton}

The 'Archaeological Ensemble of the Bend in the Boyne' (usually known as Brú na Bóinne) is one of only two current UNESCO World Heritage Sites in the Republic of Ireland and arguably its best known archaeological landscape, which contains the great Neolithic mounds of Knowth, Dowth and Newgrange. This chapter outlines what is known of the area and discusses analysis of lidar coverage of approx. $90 \mathrm{~km}^{2}$ acquired in 2006 to better inform management of the WHS and to further research in this important landscape. Detailed analysis of this dataset using multiple visualisation techniques (standard analytical hillshade; multidirection hillshade; Sky View Factor; Local Relief Modelling) was undertaken in 2010-11, revealing a range of new features of potential archaeological interest, including apparent route ways, hollow-ways, embanked enclosures and quarries, as well as providing significant new detail to some already well-known monuments. The applicability of these techniques in this landscape of subtle relief and low earthen banks, is critiqued below. Selected areas, including two previously unrecorded large enclosures (> $100 \mathrm{~m}$ in diameter) were targeted through geophysical survey, corroborating and enhancing the lidar-based picture. The use of viewshed analysis is explored, highlighting the importance of tomb visibility against views from the tombs, demonstrating that a Neolithic boat traveller's first view of the ritual landscape is likely to have been of Newgrange, while all three great tombs would only have been visible from the very apex of the Bend. Finally, while lidar data have provided a wealth of new information regarding the landscape of Brú na Bóinne attention is also drawn to significant recent discoveries which exhibit no topographic expression.

Keywords: Ireland, Neolithic, World Heritage Site, landscape, viewshed, geophysical survey, visualisation.

\section{Introduction}

The 'Archaeological Ensemble of the Bend in the Boyne' (known colloquially as Brú na Bóinne) is arguably the most widely known and best studied archaeological landscape in Ireland. Brú na Bóinne was inscribed as a UNESCO World Heritage Site (WHS) in 1993 owing to its concentration of megalithic artwork, the scale of Neolithic passage tomb construction, and the long record of continuous archaeological activity within the area (Smyth et al. 2009, 7).

The main concentration of monuments lies to the west of the town of Drogheda, within a rock-cut bend in the River Boyne as it flows eastwards to the Irish Sea. The area is defined to the north by the River Mattock, and to the south by the course of the Boyne itself. The WHS core area comprises about 780 hectares and is surrounded by a 'buffer zone' which comprises a further 2,500 hectares. At the time of the last WHS management plan there were 93 recorded monuments listed within the area (Dúchas 2002). The WHS is dominated by three massive passage tomb cemeteries - Newgrange, 
Figure 18.1: The Bru na Bóinne World Heritage Site, indicating core and buffer zones. Sites mentioned in text are labelled by letter after Coffey (1912) and O'Kelly (1978). Numbered boxes indicate areas illustrated in more detail in corresponding figures

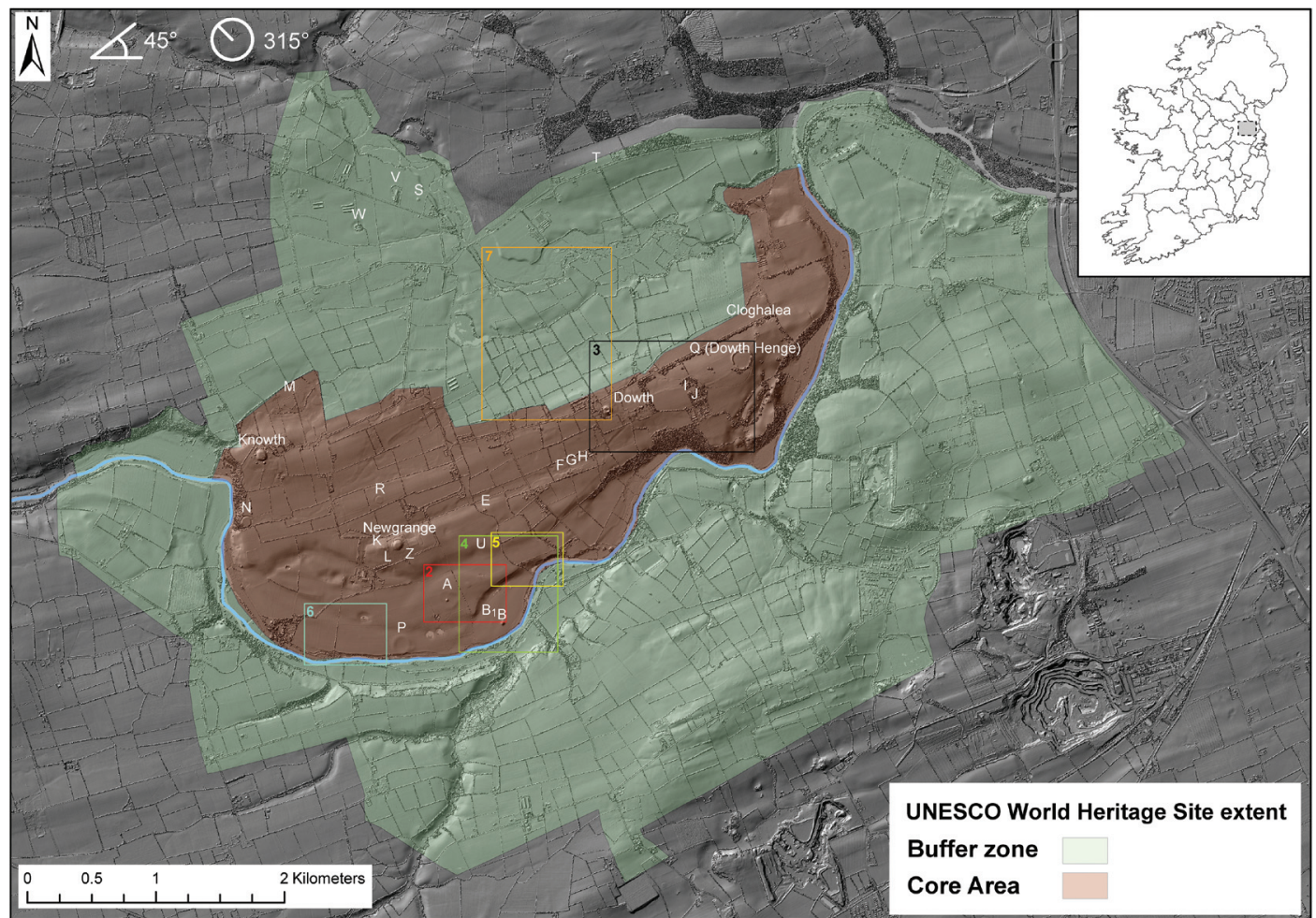

Knowth and Dowth, each of which is located at a prominent point upon an east-west shale ridge (Figure 18.1). Many sites within the WHS are known by single (occasionally double) letter codes. These are mostly derived from the early work of Coffey (1912), with addenda provided by Ó Ríordáin and Daniel (1964) and O'Kelly (1982).

Lidar data collected for the WHS has become a key part of its management strategy and is being utilized in several research projects (Corns and Shaw this volume). The use and further application of remotely sensed data at Brú na Bóinne is particularly valuable owing to the fact that only a small proportion of the WHS is under state ownership. This paper discusses the use of lidardata as a basis for research which, in addition to supporting prospection and the identification of new sites, moves toward building landscape-scale narratives. One of the challenges in building overarching narratives for the WHS is incorporating the lidar data into the dense existing archaeological record developed through excavations, survey, geophysics and aerial photography in a way that goes beyond simply adding to the corpus of sites. An overview of the archaeology of the WHS is presented here, followed by a first look at new research perspectives being explored through the combined sources of information, pursuing the goal of 'doing more' with lidar.

\section{Chronology of the WHS}

The following comprises a brief overview of the chronological development of the WHS; however, more detailed chronological overviews of the archaeology of the area appear elsewhere (e.g. Stout 2002; Smyth et al. 2009).

\section{Mesolithic - Early Neolithic}

The earliest evidence for human activity in the area is represented by a series of lithic artefacts characteristic of the Later Mesolithic period (c.5,500-4,000 BC), recovered during excavations adjacent to Newgrange (O'Kelly et al. 1983). Structural and artefactual evidence associated with the adoption of agriculture in the Early Neolithic period (c.4,000-3,600 $\mathrm{BC}$ ) is known from a number of sites within advance of the construction of the M1 motorway immediately to the east of Brú na Bóinne (O'Kelly et al. 1978; Eogan 1986; Eogan and Roche 1997; Moore 2003; Ó Drisceoil 2003; 2007). Brú na Bóinne as well as from excavations in 


\section{Middle Neolithic}

The passage tomb cemetery, which the area is best known for, was constructed mainly during the Middle Neolithic period (c.3600-3100 BC). There are at least forty possible passage tombs within the area (Eogan and Doyle 2010), with many mounds, remaining unclassified owing to lack of visible diagnostic features. Newgrange, Knowth and Dowth are the three largest, each measuring in excess of $80 \mathrm{~m}$ in diameter and dominating the Brú na Bóinne landscape

Newgrange is the best known of these three, in part owing to the deliberate alignment of passage and chamber towards the rising sun at the winter solstice (O'Kelly 1982; Stout and Stout 2008a). The mound is about $85 \mathrm{~m}$ in diameter and stands $11 \mathrm{~m}$ high. Newgrange was extensively excavated between 1962 and 1975 by Professor M.J. O'Kelly, revealing details of the construction of the passage tomb, in addition to evidence of later settlement activity dating to the Late Neolithic/Early Bronze Age (O'Kelly 1982; O'Kelly et al. 1983; Stout and Stout 2008a). Several other excavations have occurred at Newgrange, including those of Sweetman in the 1980s (Sweetman 1985, 1987 - see below).

Knowth lies at the western end of the WHS. It is similarly massive, with a diameter of about $90 \mathrm{~m}$ and a height of $15 \mathrm{~m}$. Knowth has been extensively excavated over many years by Professor George Eogan, revealing multiple phases of activity and occupation from the Early Neolithic through to the post-medieval period. Six separate phases of development during the Neolithic alone were identified (Eogan 1986; Eogan and Roche 1997).

The third of the great mounds, Dowth, was subject to limited excavation in the mid-19th century (cf. Harbison 2007; O'Kelly and O'Kelly 1983) and again in 1989 (Lynch 1990), but has never been extensively excavated. Its dimensions are similar to those of Newgrange and Knowth, with a diameter of about $85 \mathrm{~m}$ and a height of $15 \mathrm{~m}$.

Many of the smaller passage tombs and mounds, are arranged into sub-cemeteries focused on the larger mounds (Cooney 2000, 153-8; see Smyth et al. 2009, 28-9). At Knowth there is a clustering of up to 18 smaller sites, some of which have been reconstructed since the excavations. At Newgrange, a linear arrangement of mounds lies along the same ridge as the main tomb; Sites K and L lie to the west, with Site $\mathrm{Z}$ and Sites E-H to the east (cf. O'Kelly et al.
1978). Three other possible passage tombs, Sites A, B and U, lie between Newgrange and the river. At Dowth, there are further mounds and tombs (Sites I and J) while slightly farther afield, Site T is at Townleyhall and Site $S$ at Monknewtown.

\section{Late Neolithic}

There is hypothesised to have been an intensification in settlement activity in the area in the Late Neolithic (c.3,100-2,500 BC), coincident with a secondary phase of monument construction. The Boyne embanked enclosures (Sites A, P, Q and V) are believed to be of this date, in part owing to Sweetman's excavations at Monknewtown (Sweetman 1971; 1976). Best preserved of these is Dowth Henge (Site Q), a large, ovoid earthen enclosure with banks surviving to height of about $4 \mathrm{~m}$ a maximum diameter of about $150 \mathrm{~m}$. The Boyne Valley embanked enclosures form a coherent monument group and are widely distributed along both the Boyne itself and its tributaries (cf. Stout 1991). Also of Late Neolithic date is the ritual pond, Site W, at Monknewtown (Condit 1997). Previously believed to be Late Bronze or Iron Age, material obtained from the base of the enclosing ditch has been radiocarbon dated to the Late Neolithic (Brady et al. 2010).

A number of timber circles and associated structures are known from within Brú na Bóinne, both through excavation and geophysical survey, and are also believed to date from the Late Neolithic. One such timber circle was excavated at Knowth and a further two at Newgrange (Sweetman 1985; 1987; Eogan and Roche 1997). A small number of similar monuments have been recorded in excavations in the wider area including those at Coolfore, Co Louth and Lagavooren and Bettystown, Co. Meath (Eogan, J. 2000; Moore 2003; Ó Drisceoil 2003; 2007). Geophysical survey has also indicated the presence of an 'avenue' of large post pits in the field immediately to the east of Newgrange (McCarthy 2002; Kevin Barton pers. comm.) which also contains an earthen cursus monument. While this has also traditionally been seen as dating from the Late Neolithic, recent research indicates that similar monuments in the UK were constructed in the mid- to late fourth-millennium BC (Smyth et al. 2009, fig. 1.35, 22, 34; Barclay and Bayliss 1999; Thomas et al. 2009).

\section{Bronze Age/Iron Age}

The later prehistoric period has generally 
appeared underrepresented in the Brú na Bóinne landscape, with few diagnostic flint tools from fieldwalking surveys and only one Early Bronze Age cist known at Oldbridge. Recent work using aerial imagery and geophysical survey has identified a range of ring ditch features at various locations which most likely date to the Bronze Age/Iron Age period (Cooney et al. 2001; Brady 2007; Smyth et al. 2009, 37-9). Additionally, the Great Circle of standing stones around the Newgrange passage tomb have been shown to post-date the construction of the timber circle and were erected during the Bronze Age (Sweetman 1985, 208). Interpretations of anomalies identified during geophysical survey on a low-profile D-shaped enclosure about 1 $\mathrm{km}$ west of the Newgrange mound, although without exact parallels suggest a possible date from as early as the Late Bronze Age (Fenwick et al. 2009, 21-2).

Evidence from the Knowth excavations suggests an extensive period of remodelling of the main mound in the late Iron Age, converting it into a large ditched enclosure. Several burials from this time were also excavated on the site. A highly unusual hoard of Roman material is known from Newgrange, dating from the early centuries $\mathrm{AD}$. This was apparently deposited over a long time period as a series of votive offerings (Topp 1956; Carson and O'Kelly 1977; Stout 2002, 72).

\section{Early Medieval}

A number of monuments in the area have been suggested to be of early medieval date based upon their morphology. Sites N and R appear to be ringforts, a common settlement enclosure type from the period. Because of their size and prominent location, both are suggested to have been of high status (Stout 2002, 77). A further example is recorded at Rathmullan within the WHS, and there are four others recorded as cropmarking (ibid. 78). Site $M$, a series of earthwork features to the northeast of the mound at Knowth appeared to also contain one such enclosure and excavation revealed three phases of activity, during one of which the site was used as an enclosed secular cemetery (Stout and Stout 2008b).

Knowth became an important settlement focus during the early medieval period, functioning as a royal site, and it is likely that Dowth functioned in a similar way as suggested by the presence of a souterrain, an underground passage or cellar believed to function as a refuge during attacks, or perhaps as a storage area (Eogan 1977; 1990; 2007; O'Kelly and O'Kelly 1983; Stout 2002; Smyth et al. 2009; Swift 2008). Several other souterrains are known within the WHS and indicate settlement at the time (Stout 2002, 81). Further evidence of early medieval settlement has recently been uncovered at Stalleen and Rossnaree (Stephens 2009; Brady 2010, 2011). The site at Rossnaree, a multi-vallate enclosure measuring $250 \mathrm{~m}$ by $120 \mathrm{~m}$, had no obvious surface expression either in the lidar data or aerial photographs, and was first identified through geophysical survey. The nearby Hill of Slane became a major ecclesiastical centre at this time and historical sources refer to a number of monastic foundations in the area at e.g., Dowth and Rossnaree (Stout 2002, 2007; Seaver and Brady 2011).

\section{Medieval and post-medieval}

During the 12th century, Brú na Bóinne fell under the control of the Cistercian monastery at Mellifont, and saw a major reorganisation of the landscape into granges or farms. Several weirs on the Boyne may date to this period, and there are historical references to a number of mills along the river (Stout 2002; Smyth et al. 2009). The site at Stalleen (Stephens 2009), as well as producing evidence of early medieval occupation, also included evidence of 14 th century settlement, and may have been one such grange.

The Anglo-Norman lord Hugh de Lacy was granted the lordship of Meath by Henry II in 1172. A series of earthwork castles was erected across the lordship at this time, one at Knowth and a possible second at Dowth. Manorial villages were often developed at such centres and one may have developed at Dowth (Stout 2002, 95-6). A church which may have been attached to this village still stands there. Other small manorial villages would have existed in the wider landscape. Two small castles or tower-houses were constructed in the manor of Dowth, one adjacent to the church mentioned above which still stands and another at Proudfootstown which had disappeared by the end of the nineteenth century (Stout 2007, 348-9).

In the 18th century, there was extensive development of a demesne or parkland landscape at Dowth Hall. The Dowth estate included a range of landscape features, including a race course, numerous 'tree rings' (perhaps reflecting pre-existing archaeological features), a deer park 
and a 'summer house' on top of Dowth mound itself (O'Kelly and O'Kelly 1983, 138). The stone circle, at Cloghalea, much admired by antiquarian writers, was destroyed by quarrying as late as the 19th century (Stout 2002, fig. 39, 37).

\section{Remote Sensing in Brú na Bóinne: Aerial survey}

While good aerial imagery for Brú na Bóinne exists, not least through the online archive of the Ordnance Survey Ireland (three vintages are currently available - 1995, 2000 and 2005, with 2010 imagery imminent) no systematic aerial review of the area has been compiled. Some excellent oblique imagery exists, most notably through the work of Leo Swan (see Condit 2005) and Gillian Barrett (pers. comm.). Several previously unrecorded sites have been identified within the WHS through aerial survey, including the 'D-shaped enclosure' described by Swan and Condit (2000), a curvilinear enclosure associated with Site M described by Barrett and a series of cropmarks to the north of Site P, again described by Barrett (G. Barrett, pers. comm.).

\section{Remote Sensing in Brú na Bóinne: Lidar survey}

In 2006 an area of about $90 \mathrm{~km}^{2}$ was captured by the UK Environment Agency (EA) at the behest of Meath County Council. This was post-processed by the EA and supplied in the form of ASCII XYZ files, gridded to a 1 $\mathrm{m}^{2}$ per pixel resolution. These lidar data have been incorporated into a comprehensive GIS, which includes multiple diverse datasets such as Ordnance Survey Ireland (OSI) vertical aerial imagery, historical mapping, Record of Monuments and Places (RMP) information, geological information (Geological Survey of Ireland) and archaeological datasets (e.g. lithic scatter distribution and geophysical survey data (Brady 2007; Lewis et al. 2009; Brady and Barton 2010; Davis et al. 2011).

The area flown extends well beyond the current confines of the WHS, stretching almost to the village of Slane in the west and to the outskirts of Drogheda to the east (Figure 18.1). This area included a total of 279 previously recorded monuments. Visualisation initially focused on standard analytical hillshading with low solar incident angle and varying azimuth. Other visualisation methods were also employed, including multiple direction hillshades (cf.
Crutchley 2006) and Principal Component Analysis (PCA - Devereux et al. 2008), Local Relief Modelling (LRM; Hesse 2010) and SkyView Factor (SVF ; Zakšeket al. 2011; Kokalj et al. 2011). These techniques have recently been evaluated and compared by Challis et al. (2011) and Kokalj et al. (this volume).

\section{Embanked enclosures}

Of the three largest embanked enclosures within Brú na Bóinne, Sites A and P are similar in form, incorporating a semi-circular 'annex' feature to one side of the main enclosure, clearly discernible through lidar. At Site P this faces eastward enclosing the site's most obvious point of entry. An apparent second entrance, visible on a 1995 vertical aerial photograph as a small gap in the western bank, has no lidar expression and may point to a variation in bank construction rather than a physical entrance. At Site A the annex faces northeast and seems to have been subject to some quarrying (noted by Stout 1991), making the site more difficult to interpret. While the exact relationship between the annex features and the main enclosures is unclear, the lidar imagery implies (at least at Site P) that either the larger enclosure overlies the smaller or that the structure as a whole was built as a composite.

While Site P does not enclose any obvious central feature, a possible passage tomb is located centrally within the main enclosure of Site A (see above). However, it is impossible to distinguish the sequence of construction without further ground-based investigation. While Herity $(1974,145)$ suggests that the embankment was a later feature surrounding an earlier cairn it is equally possible that the mound post-dates the enclosure (similar to Bradley 1998, 113).

\section{Site $A$ and environs (Figure 18.2)}

Analysis of the lidar data has revealed significant further detail to these monuments, in particular to Site A (Figure 18.2A-D). In addition to the known annex feature, a second, smaller and very low-profile embanked enclosure with a diameter of about $64 \mathrm{~m}$ is evident to the NNW of the main enclosure, almost abutting it (Figure 18.2A). This is only evident with azimuths in the northeast quadrant (i.e. $0-90^{\circ}$ ) and is not significantly enhanced by other visualisation techniques. Application of SkyView Factor (16 directions, 10 pixel) accentuates a third annex structure to the NW of the main enclosure 
Figure 18.2: Site A and its environs. From Top Left: A) Standard analytical hillshade; B) SkyView Factor (16 direction, 10 pixel); C) Local Relief Model (indicating additional possible enclosure to west - see text) and D) 16-direction hillshade. In LRM, depressions are indicated in blue, slight elevations in red and greater elevations in yellow. Note strong visibility of subsidiary enclosure to $N N W$ in $A$ ) compared with D) and additional annex feature indicated in B)
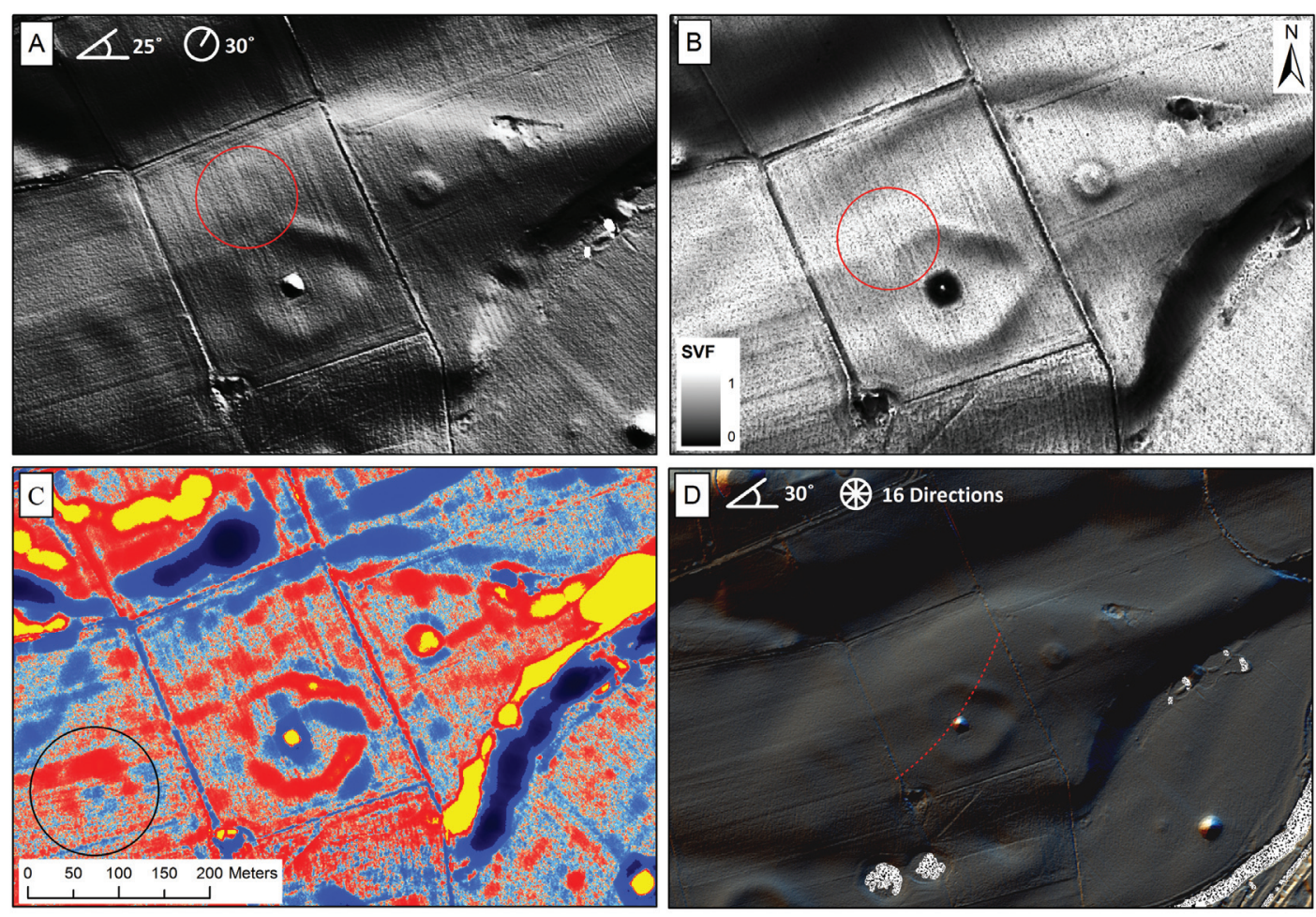

(Figure 18.2B), in form much like the known annexes at Sites A and P. The relationship between these annexes is difficult to define as both are very low profile; however, there is clearly an overlap between them, representing phased construction. Finally, the northern section of the main enclosure appears to have been intersected by a long, curvilinear cut, running approximately northeast-southwest (marked on Figure 18.2D), again best visible with specific azimuths at low solar incident angle. Clearly this last feature, cutting across all of the others, is the latest phase of development.

In the case of both Site A and Site P, slight bank deformities are evident. This is particularly clear at Site P where the annex meets the main enclosure to the south and at Site A the deformity exists to the northeast, again where annex meets main enclosure. These may represent associated structures (such as the north and south barrows at Stonehenge - cf. Bradley 1998, 96 - see also Site LP1 below) and require additional groundbased study.

\section{Site Q (Figure 18.3)}

The third of the great Boyne enclosures is Dowth Henge (Site Q - Figure 18.3A-B). The site currently has two known entrances (as postulated for Site P), one to the NE, the other directly opposite to the SW. There has been debate as to whether these represent original features, with Stout $(1991,259)$ suggesting that the northeast entrance is a later addition based on early mapping, bank morphology and the form of the immediate exterior. The incorporation of Dowth Henge into a heavily modified demesne or designed parkland landscape raises a number of questions regarding the apparently well-preserved state of this monument and the large number of cropmarks in its immediate landscape. In early mapping these are shown as 'tree rings' (i.e. circular wooded areas), and many of them have limited lidar expression. It is clear that further ground-based investigation is required to determine their nature. The interior structure of Dowth Henge differs markedly from Sites A and P: these have saucer-shaped profiles with no trace of inner scarping, while at Dowth an internal ring approximately $20 \mathrm{~m}$ wide has been scarped in the construction of the bank (cf. Stout 1991). This leaves the monument with a noticeably domed central portion. A small enclosure (c.50 m diameter) occupying the area immediately inside, but not directly aligned with, the SW entrance is visible in the lidar data. The southwest portion of this internal enclosure is missing, possibly owing to scarping in the construction (or perhaps renovation) of the main bank, giving the enclosure a 'D-shaped' appearance (Fig 3B). 

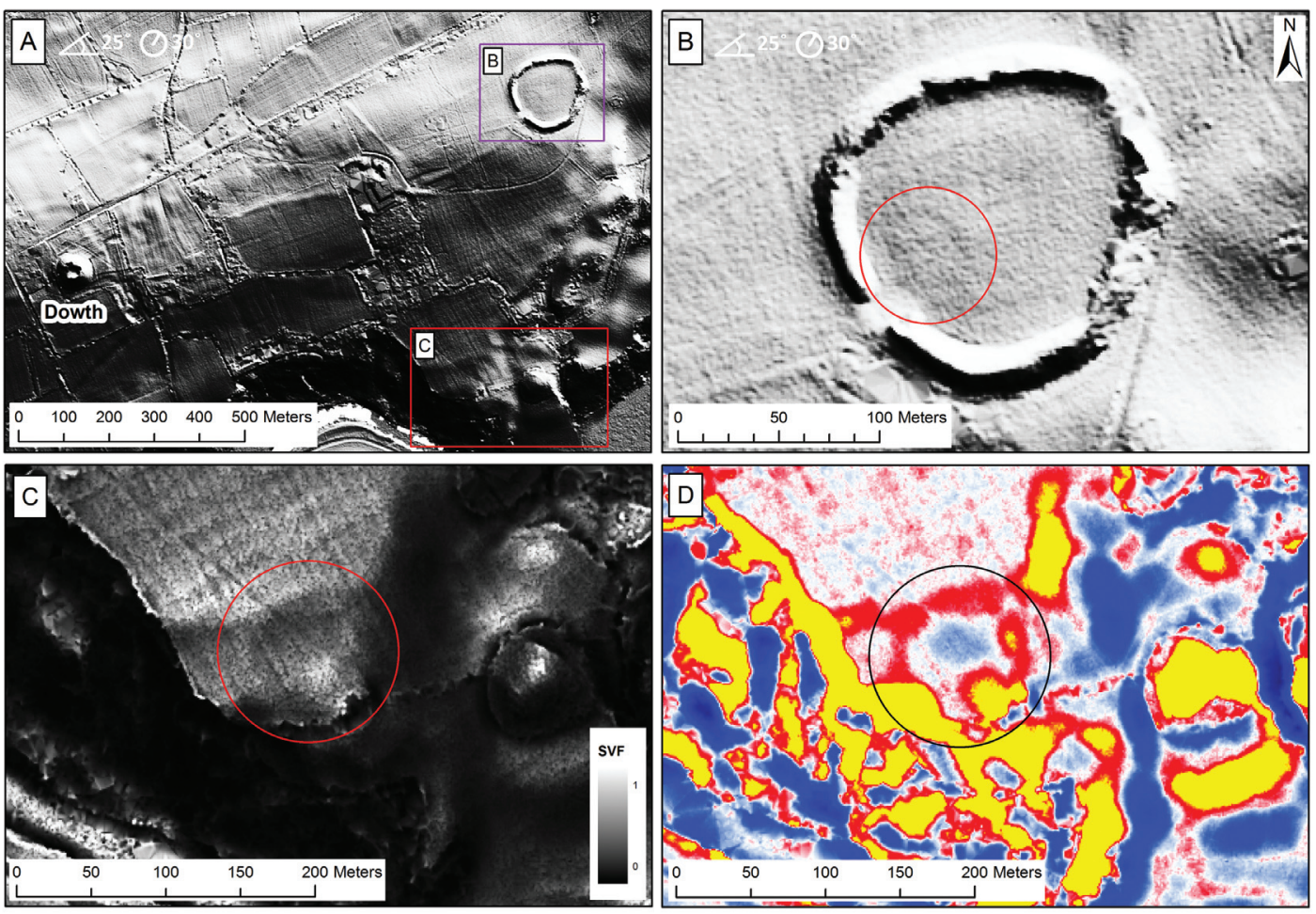

Two other features in the Dowth estate are noteworthy: a previously recorded large mound located to the southwest of Dowth Henge and the area to the west of this monument (Figure 18.3 C and D). Although not assigned a letter by either Coffey or later authors, the mound is of similar stature to those at Knowth, Dowth and Newgrange. It measures about $80 \mathrm{~m}$ across and has a 'stepped' edge, best preserved on the northern side, such as might be expected where there was a kerb (although no kerbstones are currently visible at ground level). The scale of this monument is such that these features are difficult to discern from the ground, but are clearly visible through lidar. The positioning of the site is of interest in that it is neither in a particularly prominent landscape position (contra to the mounds at Newgrange, Knowth and Dowth) nor does it command particularly expansive views (as might be expected for a motte-type feature). Approximately $120 \mathrm{~m}$ to the west, a previously unrecorded possible embanked enclosure is evident, occupying a prominence overlooking the Boyne. Visualisation of the site is complicated by a former field boundary which intersects its northern edge. However, both LRM and SVF significantly enhance this feature and appear to confirm its presence (Figure 18.3 C and D).

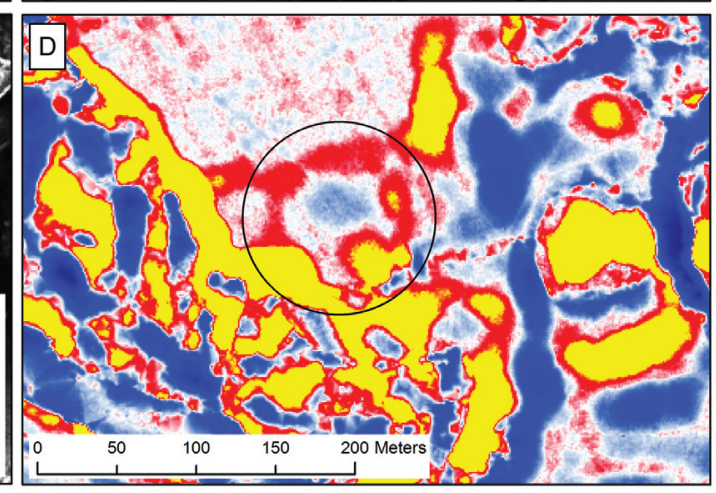

Site $B$ and its environs (Figure 18.4)

A prominent mound on the lowest terrace of the Boyne, Site B lies to the southeast of Newgrange and has been interpreted as a passage grave (Stout 2002). Immediately to the west of Site B there is a second recorded mound (Site B1 - O'Kelly, C. 1978, 50-1), described as a 'slightly raised circular area with one stone on what might be its perimeter (diam. c.15m)' (RMP record, held at http://www.archaeology.ie). From the lidar is it evident that the mound is placed slightly off-centre within a large embanked enclosure, in excess of $100 \mathrm{~m}$ in diameter. A second similar but even lower profile mound and enclosure are suggested immediately to the north. As one of the lowest-lying areas within the WHS, the presence of three palaeochannels has previously been noted here, and suggested as implying a relationship between the siting of monuments along multiple active watercourses (Lewis et al. 2009). However, lidar data reveal that the enclosure surrounding Site B1 overlies the central palaeochannel. Given the presumed Late Neolithic date of such enclosures, this implies that these channels have been inactive for several millennia.

\section{Site LP1 (Figure 18.5)}

Situated on the second terrace of the Boyne, directly above and to the northeast of Site B, a
Figure 18.3: Dowth Henge and its environs. From Top Left: A) Standard analytical hillshade; B) Detail of Dowth Henge, with interior enclosure indicated; C) Sky View Factor (16 direction, 10 pixel) image of large mound and indistinct enclosure to west; d) Local Relief Model highlighting the same enclosure in $L R M$, depressions are indicated in blue, slight elevations in red and greater elevations in yellow. 
Figure 18.4: Site B and its environs. A) Standard analytical hillshade; $B$ ) PCA of 16-direction hillshade. Note visibility of palaeochannels in $B)$ and enclosure to the west of main mound, surrounding Site B1 and overlying central palaeochannel.
Figure 18.5: Site LP1.

From Top Left: A)

Standard analytical hillshade; B)PCA of 16-direction hillshade; $C$ ) Local Relief Model and D) Magnetic gradiometry survey overlain on 16-direction hillshade. In LRM depressions are indicated in blue, slight elevations in red and greater elevations in yellow. Magnetic gradiometry data acquired on a $1 \mathrm{~m} \times$ $0.25 m$ grid.
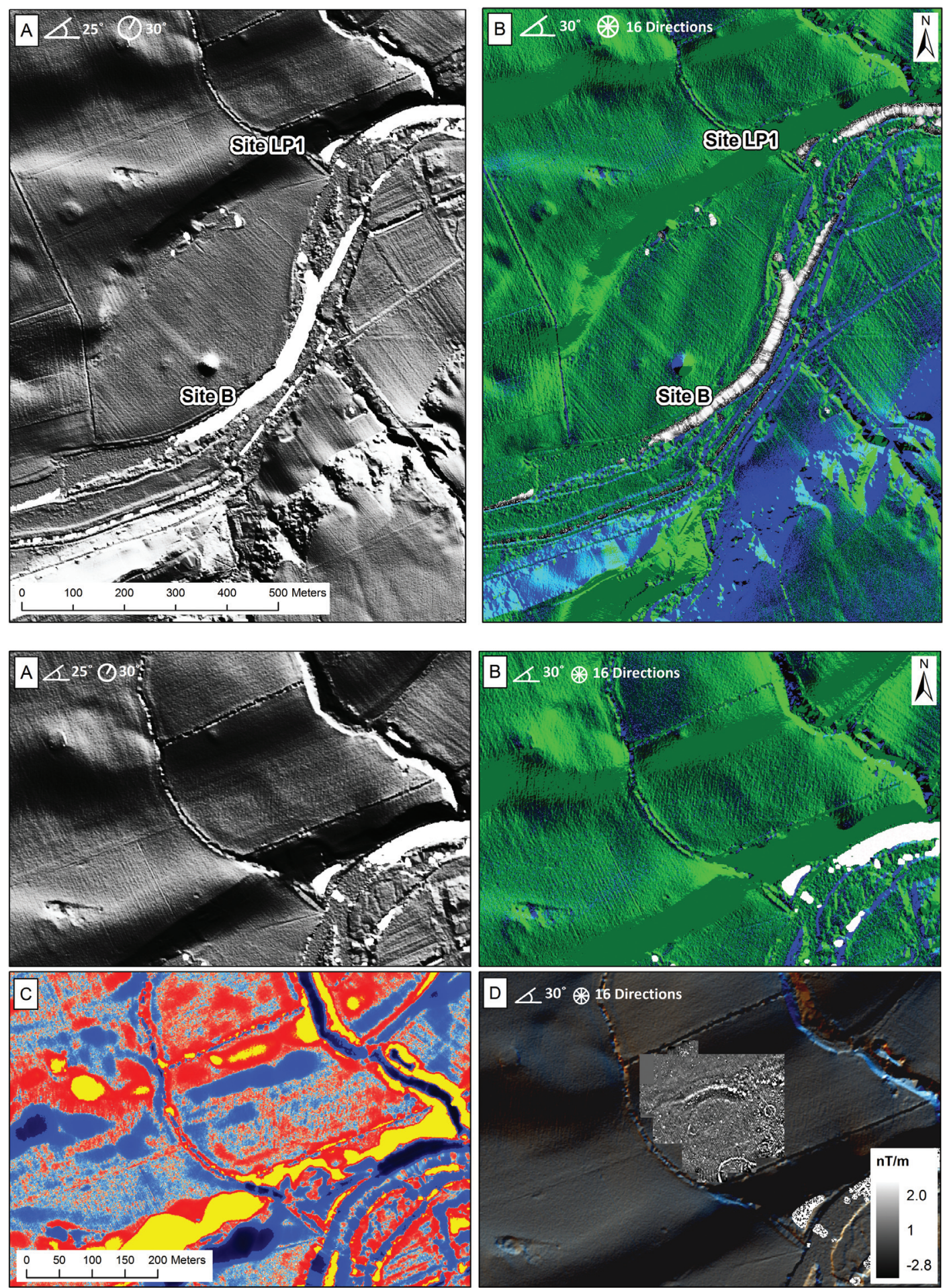

large, low-profile embanked enclosure was noted, encircling an equally low profile central mound (Figure 18.5A-C).This measures about $120 \mathrm{~m}$ in diameter with a vertical expression of some $20 \mathrm{~cm}$ and was named Site LP (Low Profile) 1. Visibility of Site LP1 was enhanced through
Principal PCA of a 16-direction hillshade and revealed a bank deformity towards the eastern side of the monument. The site was investigated using magnetic gradiometry, earth resistance and electrical resistivity tomography (ERT) (Barton 2011, 91-100). Gradiometry results revealed 

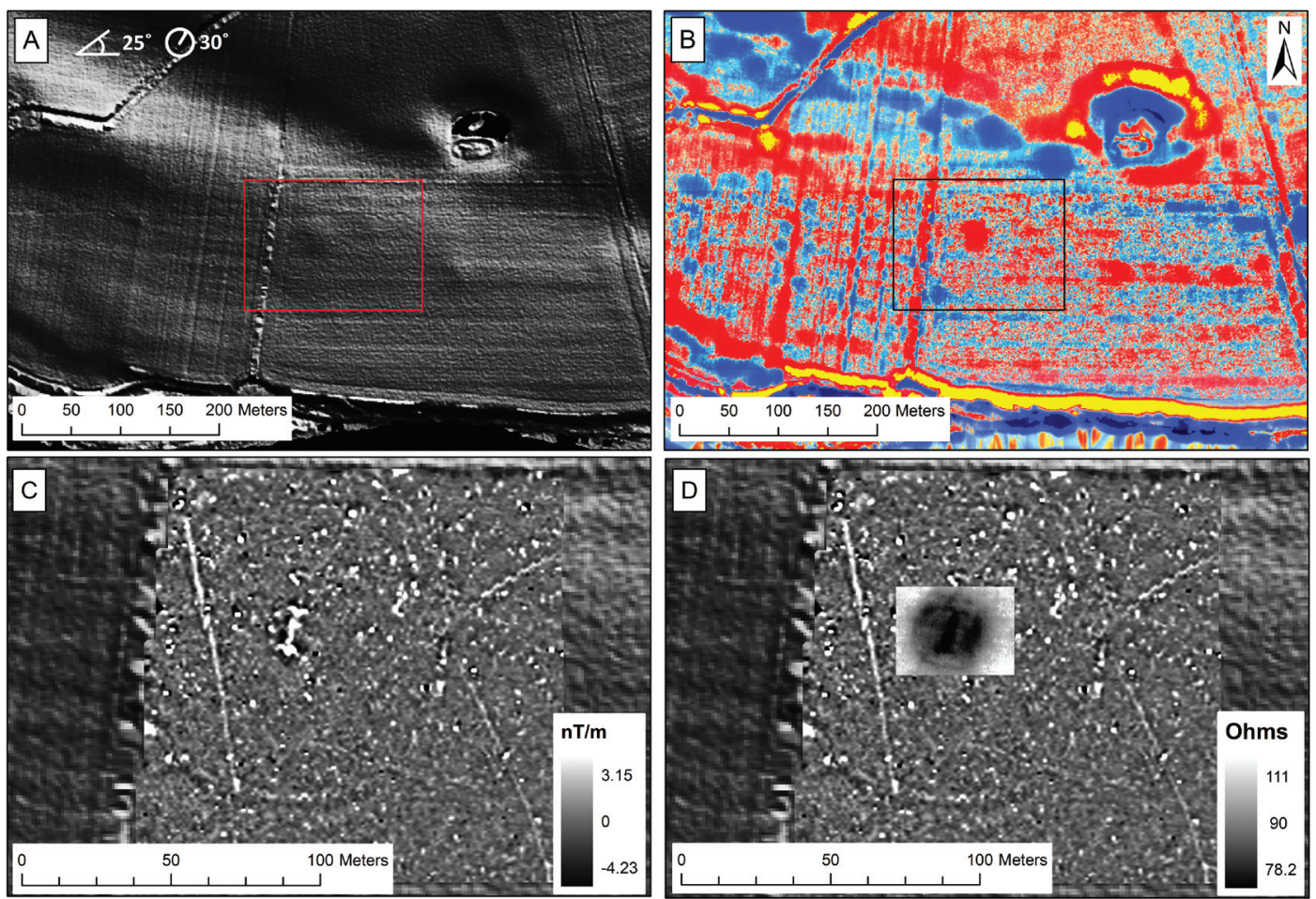

Figure 18.6: Site LP2.

From Top Left: A)

Standard analytical hillshade; B) Local Relief

Model; C) Magnetic

gradiometry survey

overlain on Local Relief

Model; D) Magnetic

gradiometry and earth

resistance survey overlain

on analytical hillshade.

In LRM depressions

are indicated in blue,

slight elevations in red

and greater elevations

in yellow. Magnetic

gradiometry data

acquired on a $1 \mathrm{~m} \times$

$0.25 \mathrm{~m}$ grid. Earth

resistance data acquired

on a $0.5 \mathrm{~m} \times 0.5 \mathrm{~m}$ grid.

two parallel curving ditches to the north side of the site. The remainder of the enclosure has little magnetic expression. Two previously unrecognised features were also recorded: to the south there is a sinuous ditch feature, while to the east is a circular ditched enclosure about 15 $\mathrm{m}$ in diameter, possibly surrounded by a ring of pits or post-holes with a diameter of about $30 \mathrm{~m}$. This latter feature does not directly correspond to the previously noted bank deformity but lies slightly to its south.

\section{Site LP2 (Figure 18.6)}

This previously unrecorded site was identified through lidar as one of a pair of low-profile mounds (maximum height $c .20 \mathrm{~cm}$, diameter c. $30 \mathrm{~m}$ ) adjacent to one of the so-called 'ritual ponds' between Newgrange and the Boyne (Figure 18.6A-B). Slight traces of an outer enclosure exist, about $140 \mathrm{~m}$ in diameter and defined by an extremely low bank, in which the mound is centrally located. This slight bank is particularly striking given the presence of substantial embanked enclosures of similar dimensions in Brú na Bóinne, and may represent an unfinished enclosure, abandoned prior to the construction of the main bank. The site was investigated using magnetic gradiometry (Figure 18.6C) and targeted earth resistance (Figure
18.6D). Gradiometry survey revealed a cut feature, $16 \mathrm{~m}$ long by $2 \mathrm{~m}$ across with splayed 'terminals' each $7 \mathrm{~m}$ long (Barton 2011, 101-12). Surrounding this is a circular cut feature about $120 \mathrm{~m}$ in diameter. The earth resistance survey focused on the central mound and identified the same feature identified through gradiometry, as well as outlining a higher resistance zone probably representing the footprint of a destroyed covering mound. The arrangement of mound incorporating a cut feature with splayed terminals suggests that this may represent the remains of a former passage tomb.

\section{Dowth routeways (Figure 18.3A; Figure 18.7)}

A sinuate raised feature was identified running from the banks of the Boyne at Dowth, past the destroyed stone circle at Cloghalea, through Dowth Henge and, passing underneath Dowth Hall, towards the tumulus of Dowth itself, a distance of about $1.6 \mathrm{~km}$. The winding nature of this feature, coupled with its association with the three principal monuments of the Dowth landscape (Cloghalea,Dowth Henge, Dowth) are suggestive of possibly earlier ritual associations, particularly given the feature apparently predates the demesne landscape. As a linear ridge, this feature is, unsurprisingly, strongly enhanced by SVF. 
Figure 18.7: Dowth Hollow-way (eastern), located NW of Dowth and running SE-NW: A) 16-direction hillshade; B) PCA of 16-direction hillshade
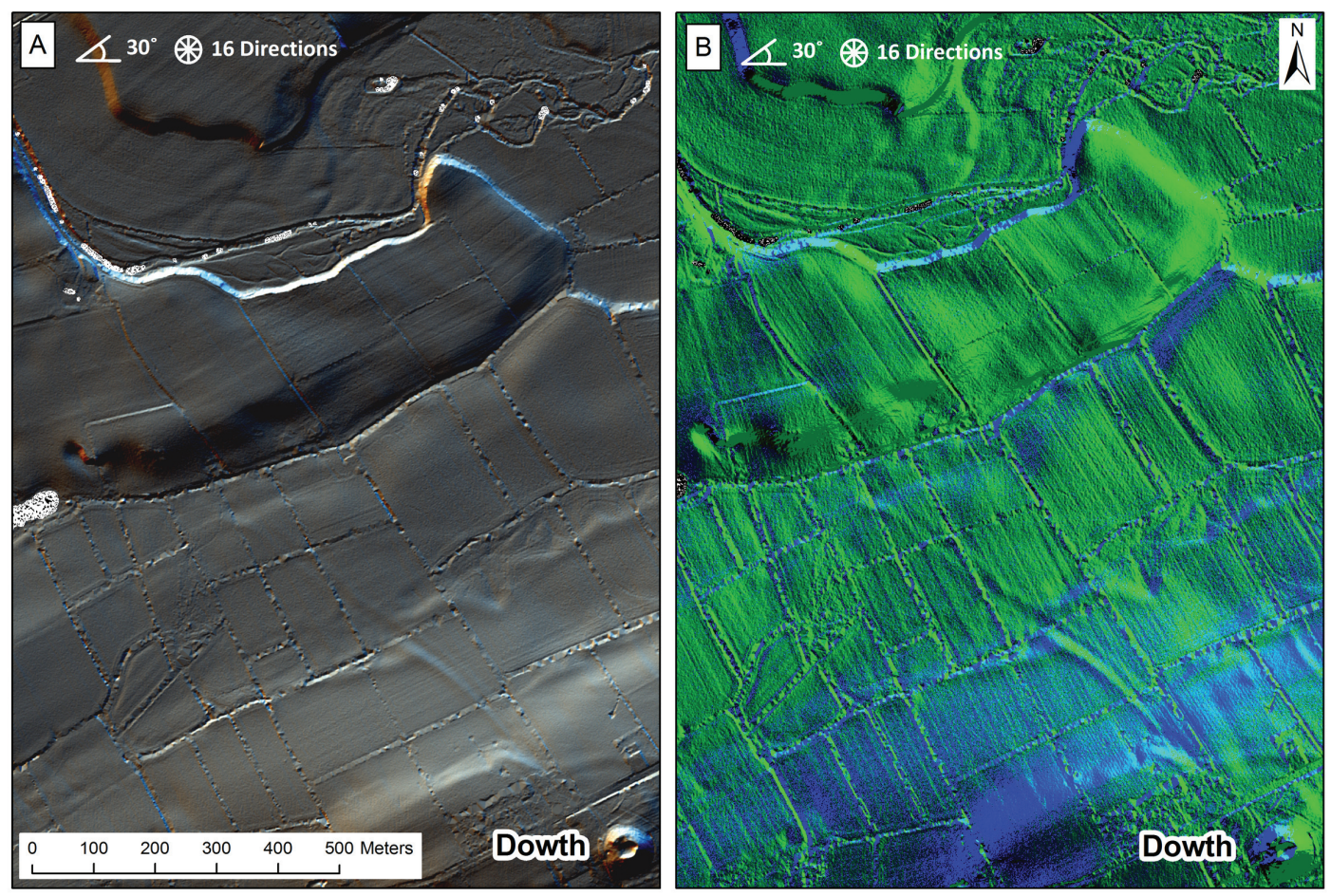

Additionally, a sinuate hollow-way, defined by two low parallel banks was identified, running from northwest of Dowth mound towards the wetland area of Ballyboy Lake, a distance of about $700 \mathrm{~m}$ (Figure 18.7A-B). At Ballyboy the feature becomes difficult to trace. However, a second hollow-way extends southwards from the western side of the lake towards a second former lake basin at Balfeddock. The antiquity of these features is impossible to determine without excavation; however, once again they do not respect field boundaries and traverse large areas of the ritual landscape, with a focus on wetland areas within Brú na Bóinne.

\section{Visualisations of the Brú na Boinne lidar: an assessment \\ Multi-direction hillshade}

Results obtained using multi-direction hillshade algorithms were mixed. While the visualisation of certain features (in particular the Dowth hollow-ways - Figure 18.7) was enhanced, in most cases little improvement was evident, and some known monuments were less visible using this approach owing to their shadows being effectively removed (e.g. Site A - Figure 18.2D). Low relief circular features (such as the low profile embanked enclosures) were particularly poorly served. A more useful approach to multidirection hillshading was to focus on a particular subset of azimuths, rather than a regularly distributed 16-direction approach. Application of PCA to these multi-direction hillshade models has produced some promising results, strongly enhancing visibility of some low profile features (e.g. Site LP1 and its subsidiary enclosure; Site B1 - Figure 18.4B; Figure 18.5B).

\section{SkyView Factor}

A number of recent papers have discussed the application and utility of SVF algorithms as an aid to archaeological interpretation of lidar datasets (Challis et al. 2011; Zakšeket al. 2011; Kokalj et al. 2011, this volume). Owing to the character of many monuments within Brú na Bóinne (i.e. relatively gently sloping mounds, banks and ditches) SVF proved of limited utility for archaeological prospection beyond what could achieved using analytical hillshading. Although visibility of some features within the WHS was enhanced (e.g. the second annex at Site A - Figure 18.2B; the low profile embanked enclosure at Dowth - Figure 18.3C), SVF performed best with stone-built structures and foundations which lay outside of the WHS but within the lidar area.

\section{Local Relief Models (LRM)}

This approach (after Hesse 2010) highlighted a large number of potential archaeological features, 
including quarry or pond features, mounds, enclosures andfield boundaries. Two areas where the technique proved particularly useful were in highlighting the presence of a possible small enclosure between Sites A and P (circled in Figure 18.2C), and apparently confirming the presence of an embanked enclosure on the promontory to the west of Dowth (Figure 18.3D). While this approach has significant potential, it produces outputs which are noisy and difficult to interpret on a landscape scale. Many features which are flagged using LRM alone are impossible to distinguish from natural hillocks and require ground-based investigation to clarify their nature. Within the Brú na Bóinne landscape it has proved most useful in exploring areas where low-profile monuments are hinted at through other methods, offering a further means of testing their validity. This echoes the views of Challis et al. $(2011,238)$ who note the utility of the method in 'visualising and isolating welldefined archaeological earthworks in low-relief landscapes'.

\section{Beyond prospection: Lidar and The Brú na Bóinne Landscape}

The principal difficulty with integrating new archaeological data obtained through lidar survey into a landscape-scale narrative at Brú na Bóinne is the lack of chronological context for the majority of sites within the WHS. For example, discussion of the Late Neolithic landscape of Brú na Bóinne is hampered by our lack of securely dated Late Neolithic monuments (e.g. embanked enclosures). Beyond glimpses of the middle Neolithic landscape of the passage tomb builders and the early medieval landscape of Knowth, Site $\mathrm{M}$ and Rossnaree there is a sizeable gap in our current understanding.

One approach which we have explored is the use of viewshed analysis. There has been much discussion of the validity of visibility studies in landscape archaeology (e.g. Thomas 2004; see also Chapman and Geary 2000), in particular questioning the value of computers in exploring how past peoples interacted with their landscapes, and commenting on their use in the context of past environmental change.

It can be argued that Brú na Bóinne is a better candidate than most for the application of these methods. As the river here occupies a rock-cut channel, its mobility throughout the Holocene has been restricted. This is evident at Site B1 and its enclosure, discussed above, indicating that even the lowest terraces of the Boyne predate much of the archaeology. While environmental data from Brú na Bóinne are limited, insect analysis of turf samples from the main mound at Knowth suggest that the immediate environment was, at the time of construction, cleared pasture, with low scrub occupying more marginal areas (Davis forthcoming; O'Donnell forthcoming). It is unlikely that dense woodland has existed here since pre-Neolithic times. As such it is probable that the large mounds would have been as visible in the past as at present (perhaps even more so given later enclosure and hedgerow development).

Using lidar-derived topographic data, a number of research questions were posed. These included: how different was the view of the landscape from the three large tombs to the view of the tombs from the landscape, and how did the view of the landscape change as one journeyed along the River Boyne? These questions addressed important issues about the visual power of the monuments, and the role of the river as a communications route.

\section{Exploring the views of and views from the tombs}

Ten points were digitised on each of Newgrange, Knowth and Dowth. A viewing radius of $5 \mathrm{~km}$ was set, accounting for the immediate landscape. By setting the landscape offset at $1.5 \mathrm{~m}$, and leaving the viewer offset at $0 \mathrm{~m}$, a viewshed was generated, showing where in the landscape each of the tombs was visible from. Knowth has the largest viewshed of $38 \mathrm{~km}^{2}$ and is visible from $48 \%$ of all land within $5 \mathrm{~km}$ of the site. Dowth has the second largest viewshed at $37 \mathrm{~km}^{2}$ or $47 \%$ while Newgrange is visible from $32 \mathrm{~km}^{2}$ or $41 \%$ of the surrounding region. The three viewsheds were then combined to generate a cumulative viewshed, showing where one, two or all three of the tombs could be seen from (Figure 18.8). This demonstrates that the tombs were more visible from the southern banks of the river and north of the River Mattock rather than from within the WHS itself. A second set of viewsheds were then generated over the same distance from the entrances of the tombs. The offsets were reversed to account for views from the tumuli. It is important to note that views were taken from two points at the entrances of the tombs, and not from the top of the mounds. Here, conversely, Knowth has the smallest viewshed with only 10 $\mathrm{km}^{2}$ visible from the entrance way, compared to Newgrange with $11 \mathrm{~km}^{2}$ and Dowth with 
Figure 18.8: Cumulative Viewshed analysis for Newgrange, showing areas visible from the tomb $v$ s. areas from where the tomb is visible

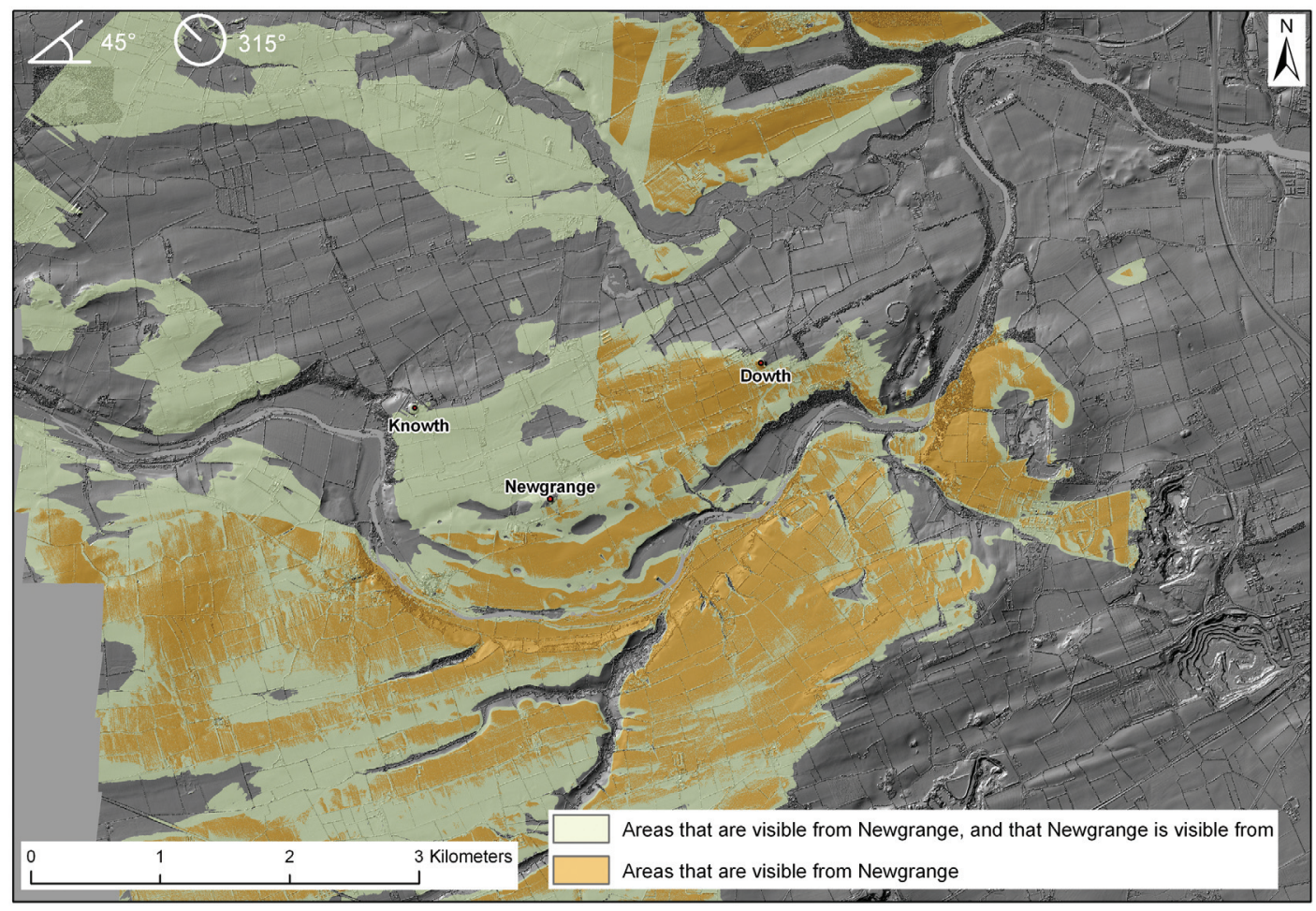

the largest viewshed of $15 \mathrm{~km}^{2}$. These views are substantially less than views of the tombs from the landscapes.

\section{Exploring how the view changes along the river} The Boyne has been a key communications route in the region for millennia, and is hypothesised as having facilitated the transport of building materials used during the construction of the passage tomb cemeteries (Mitchell 1992, 129). As previously discussed, the river has probably altered its course very little throughout the Holocene, allowing us to explore questions of changing perception of landscape through space. Key points were taken along the river and viewsheds generated from these points. A $5 \mathrm{~km}$ radius was set as was a $2 \mathrm{~m}$ offset to allow for the draught of the boat and height of the observer. In the absence of vegetation the monuments of the WHS would begin to be visible some distance to the east. However, the presence of low scrub of the type suggested by palaeoenvironmental data is likely to have obscured even the largest monuments until the traveller reached Dowth, where Newgrange would have become visible (approximately 6-7 $\mathrm{m}$ of vegetation would be required to obscure this view). The only place where all three tombs would be visible was at the apex of the Bend (adjacent to Site P), at the heart of the ritual landscape. The landscape can be interpreted as becoming increasingly revealed through movement along the river; the form of the river channel is particularly striking in this regard, with the steeply incised sections at Knowth and Dowth acting to screen the central portion of the WHS.

\section{Conclusions}

Brú na Bóinne can justifiably claim to be Ireland's most studied archaeological landscape. While in remote sensing terms it might be argued that it is matched by the Hill of Tara (e.g. Newman 1997; Corns et al. 2008), Brú na Bóinne has a history of excavation, publication and synthesis that is unrivalled. The application of lidar within this well-studied landscape has proved a revelation. New potential monuments include three enclosures (LP1, LP2 and the enclosure at Site B1) each in excess of $100 \mathrm{~m}$ diameter. A fourth enclosure at Dowth is over $80 \mathrm{~m}$ across. This has potentially doubled the number of embanked enclosures within the WHS. Site A has been revealed to be a highly complex, and most likely multi-phase monument, the large enclosure apparently overlying at least two smaller, previously unrecorded enclosures. Route ways 
of potential ritual significance also are revealed, forming an almost continuous route from the Boyne at Dowth Henge past Cloghalea, through Dowth Henge itself, to Dowth, and from there to Ballyboy, and finally to Balfeddock, a total distance of approximately $3 \mathrm{~km}$. Other low profile features have also been detected and await the opportunity to conduct further groundbased research. In total, from the 279 recorded monuments known from the total lidar survey area (93 within the WHS) at the outset of our survey, a further 132 potential archaeological features have been noted, including 68 within the WHS itself. While in many ways Brú na Bóinne is a perfect area for lidar prospection owing to its minimal woodland cover and gentle topography, comparison of a range of visualisation techniques (similar to that proposed by Challis et al. 2011) has revealed little that was not already strongly hinted at through standard analytical hillshading (see also Crutchley this volume). That is not to say that some features were not better enhanced using particular methodologies, rather that, as lidar itself is no panacea (as has been demonstrated by recent discoveries at Rossnaree - cf. Brady 2010, 2011), there is also no panacea within these visualisation methods. Clearly there is also a pressing need to follow up the completed analysis of lidar survey with additional geophysical survey and targeted excavation, as well as potentially employing other remote sensing techniques. This can be seen as a natural progression of the work begun by Smyth et al. (2009) in defining a research framework for the WHS, but is complicated by the small proportion of the WHS in state ownership.

Within Brú na Bóinne we have also sought to explore the value of lidar for more than solely archaeological prospection. Lidar has begun to help answer questions regarding past human interactions with their landscape through the application of viewshed studies. While such approaches are not without their critics, they at least serve as a starting point for discussion, and provide some fascinating insights into whether monuments were constructed to be seen or to see from, as well as regarding the interaction of the river with the ritual landscape.

\section{Acknowledgements}

Our thanks to Žiga Kokalj and Keith Challis for useful discussion on lidar visualisation and Ralf Hesse for undertaking the LRM data processing.
This research was funded by the Heritage Council INSTAR scheme and Meath County Council, and we gratefully acknowledge the contributions of all researchers who have participated in this project. We would also like to thank Gillian Barrett for helpful discussion on her aerial surveys at Brú na Bóinne.

\section{References}

Barclay, A. and Bayliss, A., 1999. Cursus monuments and the radiocarbon problem. In Barclay, A. and Harding, J., (eds). Pathways and Ceremonies: The Cursus Monuments of Britain and Ireland, 11-29. Oxford: Oxbow.

Barton, K., 2011. Part 2-Geophysical Investigations. In Davis, S., Megarry, W., Brady, C., Lewis, H., Cummins, T., Guinan, L., Turner, J., Gallagher, C., Brown, T., and Meehan, R., (eds). Boyne Valley Landscapes Project Phase III Final Report 2010, 91-129. Unpublished report for INSTAR The Heritage Council.

Bradley, R., 1998. The significance of monuments. Routledge, London.

Brady, C., 2007. A landscape survey of the Newgrange environs: earlier prehistoric settlement at Brú na Bóinne, Co. Meath. Unpublished PhD thesis, University College Dublin.

Brady, C., 2010. Excavation of an enclosure site at Rossnaree (Brú na Bóinne), Co. Meath 10E242: Preliminary Report, Excavation 2010. Unpublished report for the Royal Irish Academy.

Brady, C., 2011. Excavation of an enclosure site at Rossnaree (Brú na Bóinne), Co. Meath 10E242: Preliminary Report, Excavation 2011. Unpublished report for the Royal Irish Academy.

Brady, C. and Barton, K., 2010. Investigation of Geophysical Properties of Lithic Scatter Sites at Brú na Bóinne, Co. Meath. Interim Report Archaeology Grant 17110. Final Report. Unpublished report for the Heritage Council.

Brady, C., Davis, S. and Mulrooney, G., 2010. Part 3 - Palaeoenvironmental investigations: Augering investigation at Site W, Monknewtown 'Ritual Site - Pond' at Monknewtown Co. Meath (ME019015--). In Davis, S., Megarry, W., Brady, C., Lewis, H., Cummins, T., Guinan, L., Turner, J., Gallagher, C., Brown, T., and Meehan, R., (eds). Boyne Valley Landscapes Project Phase III Final Report 2010, 130-43. Unpublished report for INSTAR The Heritage Council.

Carson, R. and O'Kelly, C., 1977. A catalogue of the Roman coins from Newgrange, Co. Meath. Proceedings of the Royal Irish Academy 77C, 35-55.

Challis, K., Forlin, P. and Kincey, M., 2011. A Generic Toolkit for the Visualization of Archaeological Features on Airborne LiDAR Elevation Data. Archaeological Prospection 18,279-89.

Chapman, H.P. \& Gearey, B.R., 2000. Palaeoecology 
and the perception of Prehistoric landscapes, Antiquity 74, 316-9.

Coffey, G., 1912. New Grange (Brugh Na Boinne) and other incised tumuli in Ireland. Hodges, Figgis \& Co.: Dublin.

Condit, T., 1997. Late Neolithic ritual - earthen ceremonial enclosures. In Condit, T., (ed.). Brú na Bóinne, a supplement to Archaeology Ireland, $41,22-3$.

Condit, T., 2005. Some aerial photos of Leo Swan of sites in County Meath. In Condit, T. and Corlett, C., (eds.). Above and Beyond: essays in memory of Leo Swan. Wordwell: Bray.

Cooney, G.. 2000. Landscapes of Neolithic Ireland. London: Routledge.

Cooney, G., Byrnes, E., Brady, C. and O'Sullivan, A., 2001. A Pilot Archaeological Survey of the Site of the Battle of the Boyne, Oldbridge Estate, Co. Meath. Unpublished report for Dúchas, The Heritage Service.

Corns, A., Fenwick, J. and Shaw, R., 2008. More than meets the eye. Archaeology Ireland 22, 34-8.

Crutchley, S., 2006. Light detection and ranging (lidar) in the Witham Valley, Lincolnshire: an assessment of new remote sensing techniques. Archaeological Prospection 13, 103-27.

Davis, S.R., Forthcoming. The Insect Remains from Knowth. In Eogan, G. and Cleary, K., (eds). Excavations at Knowth 6: The Neolithic archaeology of the large passage tomb at Knowth, Co. Meath. Dublin: Royal Irish Academy.

Davis, S.R., Megarry, W., Brady, C., Lewis, H., Cummins, T., Guinan, L., Turner, J., Gallagher, C., Brown, A.G. and Meehan, R., (eds) 2011. Boyne Valley Landscapes Project Phase III Final Report 2010. Unpublished report for INSTAR The Heritage Council.

Devereux, B.J., Amable, G.S. and Crow, P., 2008. Visualisation of lidar terrain models for archaeological feature detection. Antiquity 82, 470-9.

Dúchas, The Heritage Service, 2002. Brú na Bóinne World Heritage Site Management Plan. Dublin: Department of the Environment and Local Government.

Eogan, G., 1977. The Iron Age-Early Christian settlement at Knowth. In Markotic, V. (ed.).Ancient Europe and the Mediterranean, 69-76. Warminster: Aris and Phillips.

Eogan, G., 1986. Knowth and the Passage Tombs of Ireland. London: Thames and Hudson.

Eogan, G., 1990. The archaeology of Brugh na Bóinne during the early centuries A.D. Seanchas Ard Mhacha: Journal of the Armagh Diocesan Historical Society 14(1), 20-34.

Eogan, G., 2007. Knowth in the Early Christian Period: the cultural and chronological context of the animal bone assemblage. In McCormick, F. and Murray, E., (eds). Excavations at Knowth 3: Knowth and the Zooarchaeology of Early Christian Ireland, 1-6. Dublin: Royal Irish Academy.

Eogan, G. and Roche, H., 1997. Excavations at Knowth 2. Dublin: Royal Irish Academy.
Eogan, G. and Doyle, P., 2010. Guide to the passage tombs at Brú na Bóinne. Wordwell: Bray.

Eogan, J., 2000. Bettystown: Prehistoric/multiperiod site. In Bennett, I. (ed.).Excavations 1998: Summary accounts of excavations in Ireland, 161. Bray: Wordwell.

Fenwick, J., Warner, R. and Eogan, G., 2009. Revealing hidden details of the ancient landscape of Newgrange, Brugh na Bóinne World Heritage Site, Co. Meath. Ríocht na Midhe XX, 5-23.

Harbison, P., 2007. In Retrospect: The Royal Irish Academy's only archaeological excavation: Dowth in the Boyne Valley. Proceedings of the Royal Irish Academy, Section C 107, 205-13.

Herity, M. 1974. Irish Passage Graves. Irish University Press: Dublin.

Hesse, R. 2010. LiDAR-derived Local Relief Models - a new tool for archaeological prospection. Archaeological Prospection 17, 67-72.

Kokalj, Ž., Zakšek, K. and Oštir, K., 2011. Application of sky-view factor for the visualization of historic landscape features in lidar-derived relief models. Antiquity 85, 263-73.

Lewis, H., Davis, S.R., Turner, J., Foster, G., Brady, C., Gallagher, C., Guinan, L., Meehan, R., Brown, A. G. and Cummins, T., 2009.An integrated, comprehensive GIS model of landscape evolution and land use history in the River Boyne valley Phase II. Unpublished report for the Heritage Council.

Lynch, A., 1990. 'Dowth', Dowth. In Bennett, I. (ed.). Excavations 1989: Summary accounts of excavations in Ireland. Bray: Wordwell.

McCarthy, M. 2002. A preliminary geophysical report on the reputed cursus at Newgrange, Co. Meath. Unpublished report for Dúchas the Heritage Service.

Mitchell, G.F. 1992. Notes on some non-local cobbles at the entrances to the passage-graves at Newgrange and Knowth, Co. Meath. Journal of the Royal Society of Antiquaries of Ireland 122, 128-45.

Moore, D., 2003. Site 19, Duleek Road, Platin. Neolithic House. In Bennett, I. (ed.).Excavations 2001: Summary accounts of excavations in Ireland, 320. Bray: Wordwell.

Newman, C., 1997. Tara: an archaeological survey. Discovery Programme Monographs 2. Royal Irish Academy, Dublin.

O'Donnell, L., forthcoming. Charcoal and wood analysis from Knowth. In Eogan, G. and Cleary, K., (eds). Excavations at Knowth 6: The Neolithic archaeology of the large passage tomb at Knowth, Co. Meath. Dublin: Royal Irish Academy.

Ó Drisceoil, C. 2003. Balgatheran Site 4: Late Neolithic ritual/settlement site. In Bennett, I. (ed.). Excavations 2001: Summary accounts of excavations in Ireland, 255-7. Bray: Wordwell.

Ó Drisceoil, C., 2007. A preliminary report concerning the archaeological excavation of Neolithic houses at Coolfore, County Louth. County Louth Archaeological and Historical Journal XXVI, 3, 260-85.

O’Kelly, C., 1978. Illustrated Guide to Newgrange 
and the Other Boyne Monuments. Third edition. Cork.

O’Kelly, M.J., 1982. Newgrange. Archaeology, Art and Legend. London: Thames and Hudson.

O’Kelly, M.J., Lynch, F. and O’Kelly, C., 1978. Three Passage-Graves at Newgrange, Co. Meath. Proceedings of the Royal Irish Academy. Section 78C, 249-352.

O'Kelly, M.J. and O'Kelly, C., 1983. The tumulus of Dowth, County Meath. Proceedings of the Royal Irish Academy 83C, 135-90.

O’Kelly, M.J., Cleary, R. and Lehane, D., 1983. Newgrange, Co. Meath, Ireland. The Late Neolithicl Beaker Period Settlement, BAR International Series 190. Oxford: British Archaeological Reports.

Ó Ríordáin, S. and Daniel, G., 1964. Newgrange and the Bend of the Boyne. London: Thames and Hudson.

Seaver, M. and Brady, C., 2011. The Hill of Slane. Archaeology Ireland Heritage Guide No. 55. Bray: Wordwell.

Smyth, J., Brady, C., Chadwick, J., Condit, T., Cooney, G., Doyle, I., Guinan, L., Potterton, M., Stout, G. and Tuffy, C., 2009. Brú na Bóinne World Heritage Site research framework. The Heritage Council, Kilkenny.

Stephens, M., 2009. Home on the Grange. Archaeology Ireland 23, 31-3.

Stout, G., 1991. Embanked enclosures of the Boyne region. Proceedings of the Royal Irish Academy 91C, 245-84.

Stout, G., 2002. Newgrange and the Bend of the Boyne. Cork University Press, Cork.

Stout, G., 2007. The church and tower house at Dowth, County Meath. In Manning, C., (ed.). From ringforts to fortified houses: studies on castles and other monuments in honour of David Sweetman, 335-51. Bray: Wordwell.

Stout, G. and Stout, M., 2008a. Newgrange. Cork: Cork University Press.
Stout, G. and Stout, M., 2008b. Excavation of a secular cemetery at Knowth Site M, County Meath, and related sites in north-east Leinster. Bray: Wordwell.

Swan, L. and Condit, T. 2000. New enclosure at Brú na Bóinne. Archaeology Ireland 14, 34-37.

Sweetman, P.D., 1971.An Earthen Enclosure at Monknewtown, Slane Preliminary Report. Journal of the Royal Society of Antiquaries of Ireland 101, 135-40.

Sweetman, P.D., 1976. An earthen enclosure at Monknewtown, Slane, Co. Meath. Proceedings of the Royal Irish Academy 76C, 25-73.

Sweetman, P.D., 1985. A Late Neolithic/Early Bronze Age pit circle at Newgrange, Co. Meath. Proceedings of the Royal Irish Academy 85C, 195-222.

Sweetman, P.D., 1987. Excavation of a Late Neolithic/ Early Bronze Age site at Newgrange, Co. Meath. Proceedings of the Royal Irish Academy 87C, 283-98.

Swift, C., 2008. The early History of Knowth. In Byrne,F.J., Jenkins, W., Kenny, G. and Swift, C. (eds). Historical Knowth and its Hinterland. Excavations at Knowth 4, 5-53. Dublin, Royal Irish Academy.

Thomas, J., 2004. Archaeology and Modernity. Routledge, London.

Thomas, J., Marshall, P., Parker-Pearson, M., Pollard, J., Richards, J., Tilley, C. and Welham, K., 2009. The date of the Greater Stonehenge Cursus. Antiquity 83, 40-53.

Topp, C., 1956. The gold ornaments reputedly found near the entrance to New Grange in 1842. 12th Annual Report of the University of London Institute of Archaeology, 53-62.

Zakšsek, K., Oštir, K. and Kokalj, Ž., 2011. Sky-view Factor as a relief visualisation technique. Remote Sensing 3, 398-415. 